\title{
Health Problems of Pre-industrial Societies
}

In this chapter we review some of the main health problems of the Ancien Régime - a term originally referring to the old political order which came to an end in the French revolution of 1789 , but here referring more generally to the pre-industrial period. We will start with war, homicide and famine, and then deal with plague, smallpox, typhus and malaria. Three other diseases involved in mortality crises, cholera, influenza and AIDs, will be dealt with later. The main question that will concern us is: how did Europeans rid themselves of these 'health problems of pre-industrial societies'? ${ }^{1}$

\section{Violence and Hunger}

\section{War}

Europe has often been a theatre of war, and wars have caused innumerable numbers of deaths throughout the three centuries covered by this book. Like homicide - with which we will deal in the following section - war and warrelated deaths are not a 'disease', so readers may wonder why they are discussed on a par with smallpox, tuberculosis and ischaemic heart disease. The answer is, first, that apart from their direct effects wars have indirect effects on population health, e.g., by precipitating epidemics (Plate 7), and, second, that in the end it does not matter whether a person dies from war (or homicide) or from disease. We would be less enthusiastic about progress in the prevention or treatment of disease if this is accompanied by an increase in the risk of death from war - and isn't that what seems to have happened in the 2oth century?

1 Leprosy, which declined even earlier than plague, and had largely disappeared from most European countries before the year 1700 , will not be dealt with in this book. Neither will yellow fever, although epidemics of this tropical disease, arriving by ship from the Americas and the West coast of Africa, heavily struck Spain and Portugal in the 18th and first half of the 19th centuries (see August Hirsch, Handbook of Geographical and Historical Pathology, trans. Charles Creighton (London: New Sydenham Society, 1883), Vol. I, pp. 335-37). Please note that this Chapter mainly focuses on causes of crisis mortality, and not on the causes of mortality in pre-industrial societies in 'normal' years. These included many of the causes dealt with in Chapter 5; see, e.g., Alex Mercer, Disease, Mortality, and Population in Transition (Leicester etc.: Leicester University Press, 1990). 


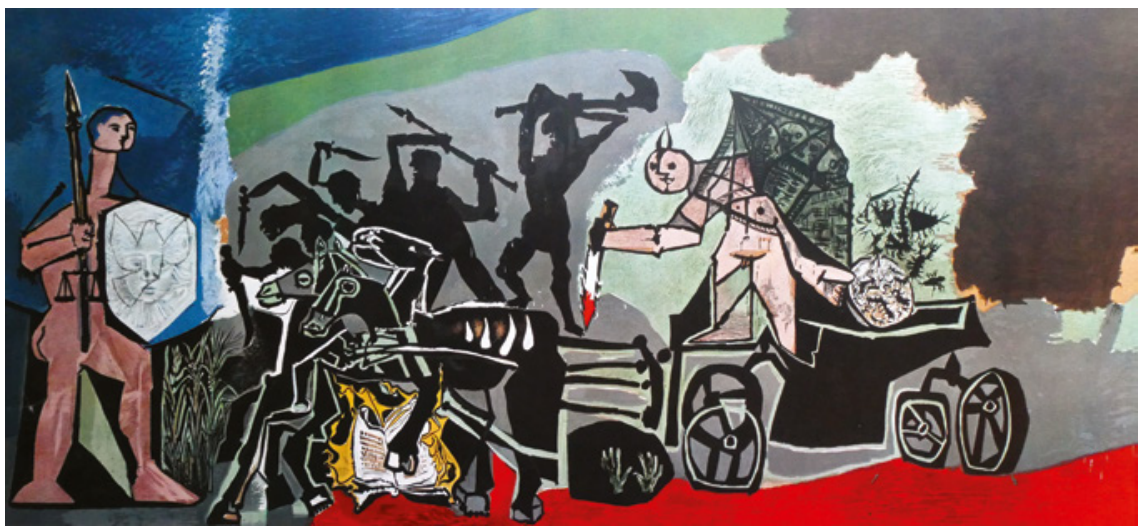

Plate $7 \quad$ La Guerre [War]. Painting by Pablo Picasso, 1951

The link between war and disease is illustrated in this lithograph, based on a wall painting with the same title by Pablo Picasso (1881-1973). Picasso executed this wall painting, together with another one illustrating 'La Paix' [Peace], in 1951 in a small chapel in Vallauris (Southern France). Less well-known than his 'Guernica', which illustrates the atrocities of the Spanish Civil War, this painting was inspired by the ravages of World War II. It shows how armed conflict is often accompanied by the spread of infectious diseases, symbolized by the black creatures escaping from the cart on the right-hand side.

(C) PICTORIGHT. REPRODUCED WITH PERMISSION

What long-term trends in the occurrence of war look like, strongly depends on how we count wars: as events, with each single war counting as one, or as the number of war-related deaths. Military historians have identified a long-term trend since the Middle Ages of decreasing frequency but increasing severity of war: since 1500, war between the great European powers gradually became less frequent, but at the same time more devastating, until the death toll peaked in the 1940 and interstate war almost stopped completely.

Let's first look at the number of war-related deaths. Counting these numbers is far from straightforward, not only because vital registration systems are often interrupted in war-time, but also because wars cause many more deaths than the military casualties that can readily be identified, and because it is difficult to draw a line between more and less strictly war-related deaths. Nevertheless, the trends are pretty clear (see Suppl. Table 5). ${ }^{2}$

2 Because famines and epidemics are treated separately in this chapter, deaths from famine and epidemics 'indirectly' caused by war are not included in the estimates of Suppl. Table 5 . If war deaths are expressed per 100,000 of the European population, we see a peak in the early 1800 s, a trough in the rest of the 19th century, another much larger peak in the first half 
The 18th century started with the War of the Spanish Succession (1701-1714, involving Britain, the Dutch Republic, Austria, Spain, Portugal, France and Savoy) and the Great Northern War (1700-1721, mainly between Sweden and Russia, but also involving Denmark, Poland-Lithuania, various German states and the Ottoman empire). Both caused hundreds of thousands of deaths substantially less than the great war of the 17th century, i.e., the Thirty-Years War which caused an estimated 6 million deaths - but disastrous nonetheless.

Between the early 18 th century and the early 2oth century several more wars occurred, of which the most devastating were the combined French Revolutionary Wars (1792-1802) and the Napoleonic Wars (1803-1815), in which France stood opposed to many other European states, and which together caused 2 million deaths. At that time, the population of Europe counted around 200 million people, which implies that a staggering $1 \%$ of the entire European population perished in this war.

Clearly, however, the 2oth century was the most deadly of the three. Estimates of deaths caused by World War I vary enormously, depending on the source and on whether indirectly caused deaths have been included, between 10 and 40 million. The conservative estimate of 10 million deaths includes 8.5 million military deaths plus 1.5 million civilians killed in hostilities on the Eastern front or dying as a result of food blockades. With a population of around 400 million people, this implies a $2.5 \%$ death rate for Europe as a whole. ${ }^{3}$

These numbers almost dwindle, however, when compared to the numbers of deaths caused by World War II. Here again estimates differ wildly, but if we again take a conservative estimate, leaving out indirectly war-related deaths, we find some 14 million military killed in action or dead of wounds, plus some 27 million European civilians killed by states, including Jews killed in the Holocaust. With a 1940 population of 550 million people, this implies a $7.5 \%$ death rate for Europe as a whole. ${ }^{4}$

of the 2oth century, and then a trough again (see Steven Pinker, The Better Angels of Our Nature (London: Allen Lane, 2011), Fig. $5^{-18}$ ).

3 This estimate excludes many millions of deaths caused by war-related epidemics, by the influenza pandemic of 1918-19, by the Armenian genocide, and by the Russian Civil War, and it excludes deaths occurring outside Europe.

4 The estimates of numbers of deaths have been taken from Davies, Europe: A History, pp. 1328329. In the Holocaust (1941-1945), Nazi Germany killed around 6 million Jews, or two-thirds of Europe's Jewish population. On top of that, the Nazis systematically killed many others, including hundreds of thousands of Roma and disabled people. 
In addition, the 2oth century also counted huge numbers of deaths due to state-based violence against civilians that was not or less directly war-related. These include the victims of the Armenian genocide in Turkey (1915, around 1 million killed), the victims of Stalin's Great Purge (1937-1938, around 1 million killed), and the victims of Franco's regime in Spain and of communist regimes in Yugoslavia, Romania and other communist countries in Central-eastern Europe (between 100,000 and 200,000 each).

The causes of all these wars and atrocities have been heavily disputed between historians, and impartiality is often difficult to find. Whereas historians agree that the blame for World War II lies squarely with Nazi Germany, opinions are more divided about the blame for World War I, but the majority opinion seems to be that here too most of the blame lies with Germany. One of the underlying factors in both wars was the expansionist drive of Germany, which as a result of rapid industrialization had become Europe's most powerful country at the beginning of the 2oth century. This expansionist drive was directed towards the East, where the Germans easily could overrun several weaker states but then collided with a mighty and ruthless competitor, Russia/Soviet Union. This explains why most of the civilian deaths in both World Wars, and most of the military deaths counted in World War II, fell in the East. ${ }^{5}$

Similarly, Russia's expansionist drives underlay several of the most bloody wars of the 19th century. These were mainly directed against the crumbling Ottoman Empire, partly in an attempt to get access to the Mediterranean. Already in the 18th century there were four Russo-Turkish Wars, and several more followed in the 19th century. The Russo-Turkish War of 1828-1829 started after Russia had helped to defeat the Ottoman fleet in the war for Greek independence. The Crimean War (1853-1856) started when Russia occupied parts of modern Romania which then were still under Ottoman sovereignty. The Ottomans had to be helped by the British and the French to - temporarily - defeat the Russians. The Russo-Turkish War of 1877-1878 was fought by the Russians to help Bulgarians, Romanians and Serbs gain independence from the Ottomans, and to gain territory for itself in the Caucasus. ${ }^{6}$

5 The historical literature on both World Wars is too vast to oversee, and still expanding. This section was inspired by Davies, Europe: A History, Chapter XI. For the impact of the struggle between Nazi Germany and the Soviet Union on the "bloodlands" of Central-eastern and Eastern Europe, see Timothy Snyder, Bloodlands: Europe between Hitler and Stalin (London: Bodley Head, 2010).

6 Between 1683 and 1914, Russia's expansion continued at an average rate of 55 square miles per day (Davies, Europe: A History, p. 869). The expansionist drives of Germany and Russia can be seen as the collective expression of a desire for better living standards - another dark side of the quest for a better life underlying population health improvements. 
After the 1940s Europe has experienced almost no further wars, with the exception of the Yugoslav Wars of the 199os. This brings us back to the longterm trend in the number of wars, which is radically different from the trend in the number of war-related deaths. Since the early 1500s, the number of European wars (counted as events per decade) has gradually declined, whereas their severity (counted in number of deaths) has increased.

This increasing severity was, to some extent, an unfavourable side-effect of the formation of the modern state. This made European countries more and more effective in waging war, by enabling them to raise the financial means for increasingly expensive, but also increasingly effective, military technologies, and by giving them the bureaucratic means to raise massive conscription armies. This has gradually raised the European death toll of war until it reached an all-time high in the middle of the 2oth century, with the carnage of World War II. ${ }^{7}$

For the decreasing frequency of war several explanations have been offered. One is that the increasing expensiveness of military technologies - which increased the severity of war - have also become an almost unsurmountablebarrier to waging war. Another is that the potential benefits of territorial conquest - which was often an important war aim in the past - have become less tempting because of the declining importance of agriculture. A third is nuclear deterrence: the almost-certainty that full-out European war would lead to even more massive destruction than the last conventional war, must also have played a role in preventing any further wars.

However, another explanation - on a more optimistic note - is that over time European countries have become inherently less belligerent. Generalized prosperity has taken away some of the economic pressures for war, and economic and political integration within an expanding European Union has increased mutual dependence and fostered better mutual understanding. War has also been 'denormalized': whereas on the eve of the World War I many Europeans looked forward to a good fight, war has since then been more or less outlawed by international treaties, and many people now feel convulsion at the thought of killing other people. This may be another, belated effect of the Enlightenment during which the first philosophical treaties denunciating

7 For trends in the frequency and severity of wars, see Jack S. Levy and William R. Thompson, The Arc of War (Chicago: University of Chicago Press, 2011). The earliest evidence for warfare in Western Europe dates from 4300 BCE, implying that the rise of warfare in Europe must have started (long) before that. Several accelerations in the frequency and/or severity of war have occurred, followed by a recent fall in the number of war-related deaths, producing an over-all pattern of rise-and-fall ("The Arc of War"), not unlike that seen for many other (health) problems of humanity. 
war saw the light. Whereas the 19th century saw the 'balance of powers' as the best way to prevent further war after the destruction of the Napoleonic Wars, countries now increasingly rely on the enforcement of international law by the United Nations, if necessary with internationally funded peace-keeping forces. ${ }^{8}$

It is paradoxical that the century in which European population health improved the most, was also the century in which wars caused more deaths than ever before. How are the two connected? Upon reflection, the connections are actually many. The main reason why wars caused more deaths in the 2oth than in the 18th or 19th century is that wars were fought with different means and with a different concept of war. Warfare had become industrialized, permitting a vastly larger scale of destruction, and were fought as 'total wars', in which civilians and civilian infrastructures were considered legitimate targets. Both changes were products of 'modernization' - more destructive weaponry was a side effect of industrialization, and the adoption of the concept of 'total war' was a product of the 'rationalization' of military-strategic thinking.

While this suggests that large-scale warfare and population health improvement have overlapping causes, we should also consider the possibility that the European wars of the 2oth century have indirectly accelerated population health improvements. They destroyed old infrastructures, such as houses and factories, which had to be replaced by new and more healthy facilities after the wars. Precisely because these were mass wars, they catalysed state involvement in public health and in social security, in order to keep the population healthy and motivated. And they increased investments in medical technology and accelerated medical innovation, which have in peace-time continued to benefit the population. Think of delousing techniques, vaccines, emergency departments and triage, surgical techniques, antibiotics, .... The best known but far from only - example is penicillin, whose development was accelerated immensely by World War II. ${ }^{9}$

8 For an analysis of the origins of war, see Jack S. Levy and William R. Thompson, Causes of War (Chichester: Wiley-Blackwell, 2011). Some down-to-earth explanations for the decline of interstate war are offered in Levy and Thompson, The Arc of War, whereas Pinker, Enlightenment Now emphasizes the role of the Enlightenment, changing attitudes and improving international diplomacy.

9 On the interrelationships between 'war, medicine and modernity', see Peter Neushul, "Fighting Research," in War, Medicine and Modernity, ed. Roger Cooter, Mark Harrison, and Steve Sturdy (Phoenix Mill: Sutton Publishing Limited, 1998). Penicillin went from a laboratory phenomenon in 1942 to mass production in 1946, thanks to a rapid transfer of knowledge and scaling up of production which would have been unthinkable without the war effort. 


\section{Homicide}

Nowadays, homicide - the act of one or more private persons killing another is a much less frequent cause of death than suicide. In most European countries the rate of death from homicide is around 1 per 100,000 per year, whereas the rate of death from suicide is around between 10 and 20 per 100,000 per year. Long ago, however, it was completely the reverse: in the Middle Ages and the early modern period, homicide was much more frequent than suicide - as if since then the aggression against other people has been internalized. ${ }^{10}$

Studies have shown that in the 1300 s and 1400s the homicide rates in England, the Low Countries, Germany, Sweden and Italy still lay between 25 and 75 per 100,000 per year. The secular decline of homicide started in England and the Low Countries in the early 1500s, with Germany and Sweden following in the 1600 , and Italy following much later in the $1800 .^{11}$

This decline has been attributed to a combination of cultural and political changes that mutually reinforced each other. On the one hand, the 'civilizing process' (Chapter 3 ) has increased the individual sensitivity to violence. Changing notions of 'masculinity' and 'honour', propagated by the church and reinforced by the Enlightenment, gradually led to a more peaceful lifestyle, first of the upper social classes and later trickling down to the lower social classes. In this process, medieval 'feuds' were first replaced by strictly regulated 'duels', and then the idea of male 'honour' disappeared almost completely, to be replaced by an ideal of 'inner virtue'.

On the other hand, the creation of the state monopoly on violence also increasingly restricted the use of physical violence in interpersonal conflicts. In the 16 th and 17 th centuries homicide was criminalized, and the judiciary started to prosecute the perpetrators. In the late 18th century, a shift in punishment occurred from fines to imprisonment, and in the 19th century many European cities established a police force which could, among other things and

10 A negative association between suicide and homicide has not only been found over time, but also comparing countries or population groups; see Jean-Claude Chesnais, Histoire de la Violence en Occident de 1800 à Nos Jours (Paris: Robert Laffont, 1981), Chapter 8. This has fuelled speculations that the suppression of aggression towards others has led to more depression and an increased tendency to self-harm; see Marzio Barbagli, Farewell to the World (Cambridge \& Malden: Polity Press, 2015), Chapter 3.

11 For systematic analyses of long-term trends in homicide, see Manuel P. Eisner, "Modernization, Self-Control and Lethal Violence," British Journal of Criminology 41 (2001): 618-38; Manuel P. Eisner, "From Swords to Words," Crime and Justice 43, no. 1 (2014): $65^{-134}$. 


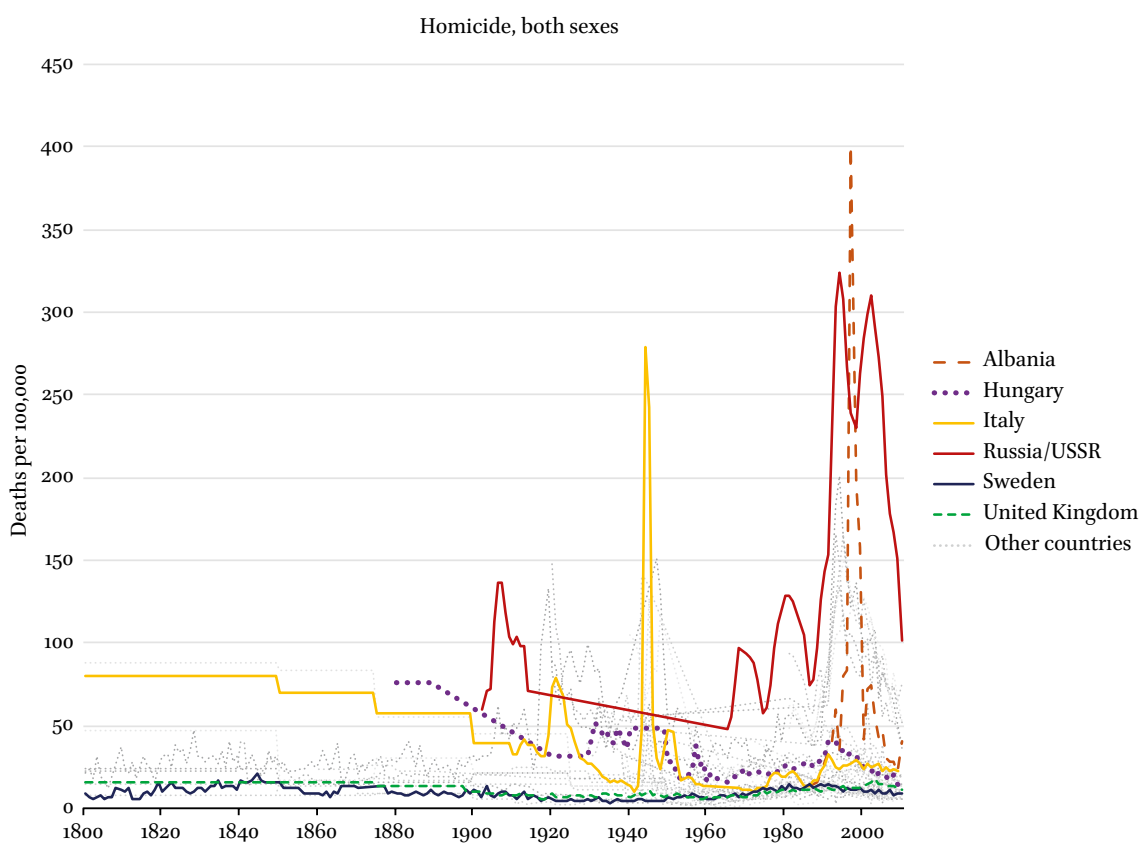

FIGURE 9 Trends in homicide in Europe, 1800-2010

SOURCE OF DATA: WWW.CLIO-INFRA.EU (ACCESSED 28/08/2018)

sometimes against the protests of the local population, investigate crimes and try to apprehend suspects. ${ }^{12}$

Figure 9 shows trends in homicide in European countries since 1800. In view of what has just been said, it is important to keep in mind that this figure does not capture the secular decline of homicide rates that occurred in Western and Northern Europe in the preceding period. For example, in the year 1800 the homicide rates in England, Belgium and Sweden were already down to 1 or 2 per 100,000 per year. We do, however, see that Southern European countries such as Italy (and Spain, not highlighted in the graph) were still in the process of reducing their homicide rates from the much higher pre-modern levels.

When we take 1800 as our starting-point, what strikes us most in Figure 9 is, first, the absence of a general decline in homicide and, second, the enormous 'spikes' in homicide mortality that keep returning throughout the 19th and 2oth centuries. It is thus not immediately clear from the graph that

12 On comprehensive explanations of long-term trends in homicide, see Chesnais, Histoire; Pieter Spierenburg, A History of Murder (Cambridge: Polity Press, 2008). An attempt to relate the decline in homicide to the increase in 'social disciplining' and 'self-control' can be found in Eisner, "Swords." 
Europe-as-a-whole has made much progress in eliminating homicide mortality. It is important, therefore, to look in more detail at what has happened. What we see in Figure 9 is the result of at least four superimposed processes.

First, homicide rates in the Western European countries in which homicide rates were already very low in the early 1800 , have followed a pattern of slow, and sometimes multiple, but always modest 'rises-and-falls'. For example, in Sweden homicide rates rose somewhat during the first half of the 19th century, then declined for a very long period, rose again in the second half of the 2oth century, and then started to decline again. In many European countries - also in the South and East - homicide rates reached their lowest point ever in the 1940 and 1950s, and have since risen again.

The minimum values obtained in the middle of the 2oth century have been interpreted as the result of the long-term 'civilisation process' mentioned above. The increase since then has been interpreted by some as a temporary 'reversal of direction' of this process, i.e., a 'de-civilising process' resulting from the loosening of norms in the 196os. However, because homicides within the family did not increase at all, others have suggested other explanations. These point to violence between non-European immigrants among whom male 'honour' is still important, proliferation of organized crime leading to violent conflicts between drug dealers and other criminals, and increased night-time recreation with alcohol intoxication. ${ }^{13}$

Second, homicide rates in many less advanced countries have converged, to a greater or lesser degree, towards the low values already obtained in a number of Western European countries in the early 180os. This is what happened in, for example, Italy and Spain during most of the 19th century, and in Hungary during a large part of the 2oth century (Figure 9). Because this process of convergence was slow, it resulted in starkly contrasting homicide rates within Europe during most of the period observed.

In the 19th century, Europe became divided in an inner and an outer zone, with the outer zone consisting of Ireland, the Mediterranean, the Balkans, Eastern Europe, and Finland, where homicide rates remained high. Within their respective countries, the islands of Corsica, Sardinia and Sicily also long kept their higher homicide rates. This has been attributed to cultural delays (e.g., extended family ties and honour remaining important for longer) combined with

13 See Manuel P. Eisner, "Modernity Strikes Back?," International Journal of Conflict and Violence 2, no. 2 (2008): 288 - 316 and Spierenburg, History for an analysis of these recent trends. Pinker, The Better Angels of Our Nature, Chapter 3, has argued for the role of a 'decivilising process', due to the rise of anti-authoritarian attitudes in the 1960s. A similar explanation has been suggested for the rise of sexually transmitted diseases (see Chapter 5, Syphilis). 
delays in the creation or imposition of the state monopoly on violence (e.g., persistence of knife fighting, feuding, and banditry). It was only after World War II that these contrasts in homicide rates between North and West on the one hand, and South and East on the other hand, more or less disappeared. ${ }^{14}$

Third, superimposed on these longer-term processes are several massive increases in homicide rates coinciding with episodes of political disruption. For example, homicide rates in Finland spiked in the early 1900 s in connection with the 1905 Russian revolution, and then again around 1920 in the aftermath of the civil war that resulted in Finland's independence from Russia. Homicide rates in Russia itself spiked in the early 1900 s as well, as they did in the late 1990 s and early 2000s, in connection with the political and economic disruption after the collapse of the Soviet Union. Homicide rates in Italy spiked in the last years of World War II, as they did in many other European countries. The largest spike of all occurred in 1997 in Albania, when the 'pyramid crisis' resulted in massive civil unrest and violence between armed gangs, the police and civilians. ${ }^{15}$

Clearly, this is a different type of homicide as compared to the interpersonal violence seen in normal times. In war-time, the normal restrictions on the use of violence, both psychological and judicial, partly disappear. Conflicts between opposing parties are not only fought by armies, but also, and usually on a smaller scale, by civilians, as in resistance movements or retaliations for actions of the other party. Nevertheless, these massive spikes, in which homicide rates briefly rise to medieval levels, illustrate the fragility of the social fabric that protects us from wide-spread violence in normal times.

Fourth and finally, some of the homicide trends and variations seen in Figure 9 reflect changes and variations in one of the most important risk factors for homicide: excessive alcohol consumption. Both in the past and nowadays, many acts of homicide are committed during a fight between two persons, usually young or middle-aged men, who are both under the influence of alcohol.

14 See Chesnais, Histoire, Chapter 2, and Spierenburg, History, Chapter 6, for an analysis of these contrasts in homicide rates within Europe.

15 In 1905 Finland was still part of the Russian empire. On trends in Finland's homicide rates, see Jukka Savolainen, Martti Lehti, and Janne Kivivuori, "Historical Origins of a CrossNational Puzzle: Homicide in Finland, 1750 to 200o," Homicide Studies 12, no. 1 (2008): 67-89. Although data on homicide in Russia/Soviet Union are not available between the start of World War I and the mid-196os, we know that the Civil War following the October 1917 revolution was accompanied by a massive rise in homicide; see Chesnais, Histoire, Chapter 14. On the Albanian 'pyramid crisis', see Chapter 7. 
Finland's high rates of homicide arose in the early 19th century, when, due to ample availability of alcohol, binge drinking became common in newly established forest-industrial towns and lumber-producing rural communities. During the 2oth century, Finland's rates converged somewhat with Sweden's, but a new rise in homicide started in the late 196os after the relaxation of alcohol control measures. To a large extent, the connection between excessive alcohol consumption and homicide also 'explains' the levels and variations in homicide in Russia and other countries of the former Soviet Union. ${ }^{16}$

\section{Famine}

As we saw in Figure 2, until quite recently large-scale famine was a very important cause of mortality crises in Europe. The origins of these famines were often complex. In early modern Europe a single crop failure due to bad weather was no longer enough to produce starvation, because public stores of grain and commercial trade with other, non-afflicted areas could compensate for temporary shortages of food.

Famines were therefore usually due to a combination of factors, such as rapidly rising population numbers plus a succession of harvest failures. Disastrous human intervention could also produce a famine, for example in World War II during the infamous German siege of Leningrad in 1941-44 (Plate 8) and during the 'Hongerwinter' in the Netherlands in 1944. ${ }^{17}$

Famines must have accompanied humans since at least the Neolithic period. This is because agriculture allowed them to increase their numbers, but also made them dependent on a limited number of self-grown foods, whose growth was subject to weather and other conditions beyond their control. Over time, however, the severity of famines declined: so-called super-famines in which many millions of Europeans perished, all occurred before the 18th century. The last of these super-famines occurred in the 169os. On a very long

16 See Savolainen et al., "Historical Origins of a Cross-National Puzzle" for the history of homicide in Finland. Many studies have shown an association between excessive alcohol consumption and homicide in Russia, e.g. Yury Razvodovsky, "Homicide and Alcohol Intoxication in Russia, 1956-2005," Alcoholism 43, no. 1 (2007): 36-50.

17 See Guido Alfani and Cormac Ó Gráda, "Famines in Europe: An Overview," in Famine in European History, ed. Guido Alfani and Cormac Ó Gráda (Cambridge etc.: Cambridge University Press, 2017) for a general overview of the factors causing European famines. The Dutch 'Hongerwinter' had a complex explanation, including a strike by Dutch railway personnel (in response to a call from the exiled Dutch government to help the advance of the allied troops) and a German blockade of inland shipping; see Ingrid de Zwarte, $D e$ Hongerwinter (Amsterdam: Prometheus, 2019). 


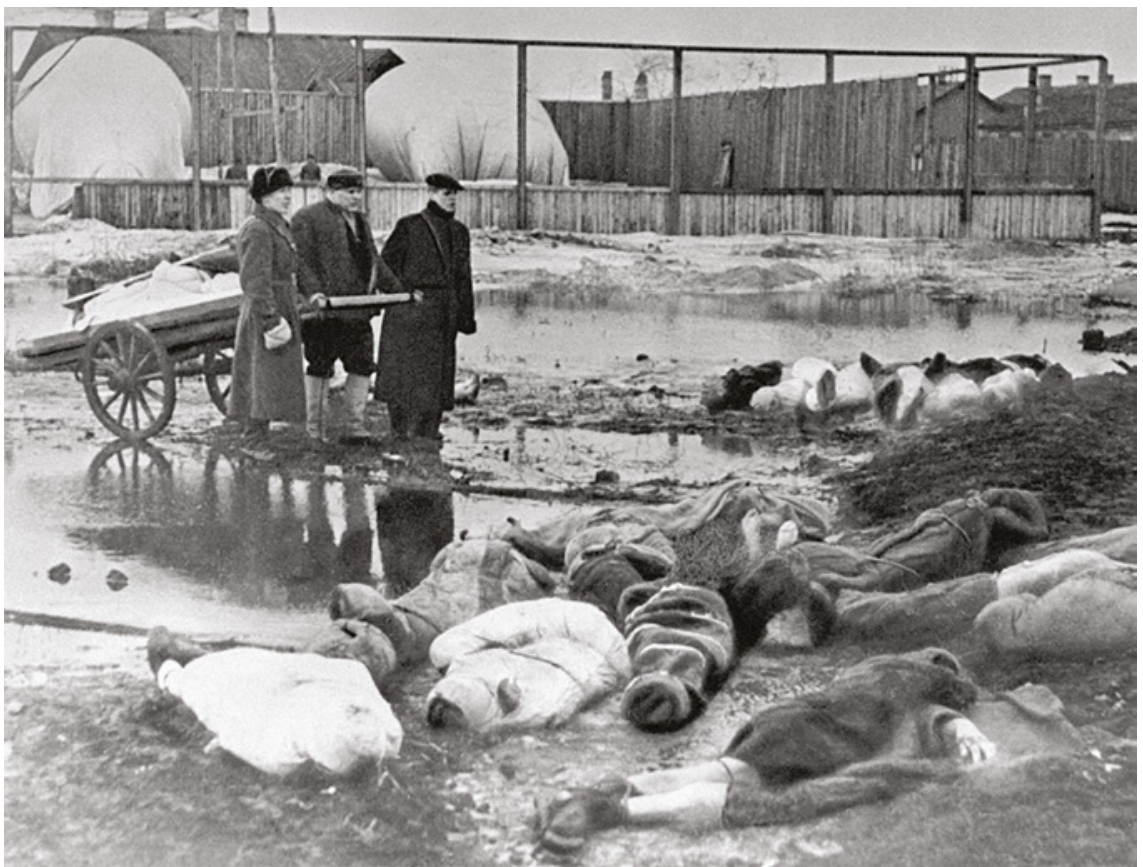

PLATE 8 Three men burying famine victims during Leningrad's siege, 1942

During European history, wars have often caused famines. The siege of Leningrad by the German army during World War II started in 1941 and lasted for two-and-a-half years, causing 1.5 million deaths, mostly by starvation. Many people died on the streets. Photograph by Boris Kudoyarov HTTPS://COMMONS.WIKIMEDIA.ORG/WIKI/CATEGORY:VOLKOVSKOE_CEMETERY\#/MEDIA/FILE:RIAN_ARCHIVE_216_THE_VOLKOVO_ CEMETERY.JPG (CC BY SA 3.0; ACCESSED 18/10/2019)

time-scale, famine's secular trend is therefore characterized by a pattern of 'rise-and-fall', just like many other health conditions. ${ }^{18}$

The gradual decline of the risk of famine was due to favourable changes in its structural determinants. Extreme meteorological events became less severe or frequent when the Little Ice Age came to an end, which may have contributed to a lower frequency of crop failures. More importantly, the availability of food increased at a faster rate than population numbers increased, due to an 'agricultural revolution'. (Not to be confused with the Neolithic or first

18 According to Alfani and Ó Gráda, "Famines in Europe" table 1.1, three super-famines that struck large parts of the European subcontinent and killed many millions of people occurred in $1315^{-17}, 1590-98$, and $1793^{-9}$. 
agricultural revolution.) This (second) revolution started in the 17th and 18th centuries in England and the Low Countries, and later spread to the rest of the European continent. It is not a coincidence that England was the first European country to remain free of famine. ${ }^{19}$

This agricultural revolution had two main components: an increase in agricultural output, and a change from subsistence farming to production for national and international markets. Agricultural productivity was increased by new systems of crop rotation, introduction of new foods like the potato, and expansion of arable land by drainage of lakes and marshes. Breakdown of regulations on marketing and improvements in transport allowed farmers to specialize and produce for the market, which would in the 19th century lead to the globalization of food trade networks and increased availability of non-locally grown food. ${ }^{20}$

However, although these changes gradually reduced the risk of famine, two counter-forces ensured that famines continued to occur into the 19th and 2oth centuries (for some of the largest famines occurring after 1700, see Suppl. Table 6). Some countries became strongly dependent on a single crop, such as potatoes or maize, which increased their vulnerability to crop failures. And as warfare became more large-scale, hostilities more often led to wide-spread famine.

Famines in the 18th century were less severe than those in earlier centuries, but several major famines still occurred, including the 'Great Frost' of the 1740s which caused a visible spike in mortality in the Nordic countries (Figure 2). The most notorious among the 19th century famines are those of $1816-17,1845^{-}$ $5^{0}$, and 1866-68. The first followed the eruption of Mount Tambora in presentday Indonesia, whose dust clouds caused a European 'Year without a Summer' in 1816 . The third was due to an exceptionally rainy and cold summer in 1866

19 The Little Ice Age (ca. 1400 - 180o) reached its minimum temperatures around 1650. European fine art museums still exhibit the romantic skating scenes that this period of severe winters produced, but this was also a period in which harvests suffered and epidemics raged; see Brian Fagan, The Little Ice Age (New York: Basic Books, 200o); Alfani and Ó Gráda, "Famines in Europe" . However, for a different view-point see Morgan Kelly and Cormac Ó Gráda, "The Waning of the Little Ice Age: Climate Change in Early Modern Europe," Journal of Interdisciplinary History 44, no. 3 (2013): 301-25. England suffered famines until the mid-17th century but remained free since then, in contrast to other European countries; see Richard Hoyle, "Britain," in Famine in European History, ed. Guido Alfani and Cormac Ó Gráda (Cambridge etc.: Cambridge University Press, 2017).

20 See Mark Overton, Agricultural Revolution in England (Cambridge etc.: Cambridge University Press, 1996) for an analysis of the agricultural revolution in England. 
and a succession of crop failures in Northern and Eastern Europe, and is also clearly visible in Figure $2 .{ }^{21}$

The second, the 'Potato Famine' of the 1840 s, is one of the best documented. This is because it occurred at a time when a keen interest in quantification was already present in many European countries, and some countries already kept death registers. Although several countries in North-western Europe were struck, Ireland was struck the most severely. The best estimate for the total number of deaths caused by the 'Great Irish Famine' is 1 million, or around $12 \%$ of the Irish population. ${ }^{22}$

As was so often the case, the causes of this famine were complex. A mold disease, 'Potato Blight', partially destroyed several potato crops in a row, and as the Irish people were highly dependent on this staple food large-scale starvation ensued. Yet, other factors also played a role, such as the rapid increase in population numbers of the preceding decades, suggesting that the rise of mortality also represented a 'Malthusian crisis'. Furthermore, the response of local and national government (Ireland was still part of the United Kingdom and governed from London) was callous. Poor farmers were evicted from their lands without regard to their livelihood, and famine relief was grossly insufficient. $^{23}$

In the 2oth century, large famines continued to occur, but now mainly as an accompaniment of international or civil war. The main famines of the 2oth century occurred in the Soviet Union. The civil war following the Bolshevik revolution led to a famine in 1917-22; a combination of drought and disastrous policies led to famine in Ukraine and parts of Russia in 1927-33; and a combination of crop failures and the destruction of World War II led to a severe famine in Moldova in 1946-47.

Each of these famines caused at least 1 million deaths, but the 1933 famine was the worst of all, with a death count amounting to 2.5 million in Ukraine alone. This famine was different from the other two 2oth century famines in

21 The 'Great Frost' famine, and the way it influenced mortality rates in Europe, has been analysed in John D. Post, Food Shortage, Climatic Variability, and Epidemic Disease in Preindustrial Europe (New York: Cornell University Press, 1985). Post argues that social disarray, including the failure of famine relief measures, was as important as undernutrition in causing excess mortality.

22 Although these deaths occurred over several years, the Irish spike in mortality in the late 1840 s would have been one of the highest in Figure 2, if only national mortality rates for Ireland would have been available for plotting.

23 The causes of this famine, and particularly the role of the British government, has been fiercely debated. A monument to the famine in Belfast even speaks of 'genocide' on the Irish people. See Ó Gráda, "Ireland" for a balanced discussion. 
the Soviet Union because it occurred in plain peace-time. It has therefore given rise to accusations of 'genocide' on the Ukrainian people by Joseph Stalin. This idea is also captured in the name given to this famine, 'Holodomor', which literally means 'killing by starvation'. Although there is no convincing proof that there was an intent to kill on the part of the Soviet authorities, the forced collectivization of agriculture that Stalin pursued in these years, the redirection of food from grain-producing areas to urbanized regions in the North of Russia, and lack of adequate famine relief certainly played a role. ${ }^{24}$

\section{Great Epidemics}

\section{Plague}

Plague, the disease which we now know to be caused by infection with Yersinia pestis, has produced some of the most devastating epidemics which mankind has ever encountered. Before the modern era, 'plague' used to be a general name for all diseases with high mortality, but some stories about 'plagues' in the Bible and Herodotus contain details about symptoms suggesting that plague in its current sense already occasionally raged in the Middle East before the Common Era. ${ }^{25}$

Plague is a disease that can manifest itself in several forms: 'bubonic plague' (infection of the lymph nodes), 'septicemic plague' (infection in the bloodstream), and 'pneumonic plague' (infection of the lungs). It is spread through the bites of infected rat-fleas, but in the case of 'pneumonic plague', the most lethal version, also from person to person through air-droplets. The responsible micro-organism, Yersinia pestis, circulates in animal reservoirs, particularly in rodents, and plague pandemics which reached Europe probably originated in reservoirs in remote Asian regions. The disease had a short incubation period and very high case fatality, causing great panic in affected populations. ${ }^{26}$

24 The estimate for Ukraine is from Jacques Vallin et al., "A New Estimate of Ukrainian Population Losses During the Crises of the 1930s and 1940s," Population Studies 56, no. 3 (2002): 249-64. This famine also caused at least 1 million deaths in Russia; on the causes of this famine, see Stephen G. Wheatcroft, "Eastern Europe (Russia and the USsR)," in Famine in European History, ed. Guido Alfani and Cormac Ó Gráda (Cambridge etc.: Cambridge University Press, 2017).

25 For the ancient history of plague, see, e.g., Hirsch, Handbook vol. I, pp. 494-96.

26 This paragraph is a short summary of the current consensus on the aetiology of plague, and ignores several scientific controversies, such as whether or not the human flea can transmit the disease. For an overview of unexplained aspects of plague epidemics, see Paul Slack, "The Black Death Past and Present. 2. Some Historical Problems," Transactions of the Royal Society of Tropical Medicine and Hygiene 83, no. 4 (1989): 461-63. DNA testing 
Plague struck Europe long before national or even municipal statistical data were collected, so reconstructing the timing and diffusion of plague epidemics has been a matter of studying archival sources. Like other diseases, plague is characterized by a clear pattern of 'rise-and-fall', in this case in several waves stretching over some 1500 years. The decline of plague started before the 18th century, but because several epidemics still occurred in Europe after the year 1700 we will briefly discuss its history and the reasons for its decline. ${ }^{27}$

The first documented plague epidemic in Europe was the 'Justinian plague', which arrived in Constantinople from the Middle East in 542. It spread along the coasts of the Mediterranean and into Southern Europe along seafaring routes and along rivers, causing huge numbers of casualties in the 540s. After this first wave, the plague returned in cyclical patterns throughout the 6th, 7th and 8th centuries, always arriving from the East. It mysteriously disappeared after a last epidemic in the $760 \mathrm{~s}$, perhaps due to an interruption of long-distance trade with Asia as a result of the Islamic conquests of the Mediterranean.

The second plague pandemic reaching Europe from Asia was the 'Black Death', which arrived in Constantinople in 1347 on board a Genoese ship coming from the Crimea, where during a siege the Tartars had catapulted the bodies of plague victims into the Genoese trading post of Caffa. The disease spread along the coasts of the Mediterranean, the Atlantic, the North Sea and the Baltic into most of Europe, always arriving in port cities and travelling along trading routes. It caused huge numbers of casualties in the late 1340s, perhaps up to 25 million in Europe as a whole, and its massive mortality probably caused profound changes in European culture. ${ }^{28}$

of victims of the plague in London (1348) and Marseille (1722) has confirmed the presence of Yersinia pestis in their dental pulp; see Michel Drancourt et al., "Detection of 40o-YearOld Yersinia Pestis DNA in Human Dental Pulp," Proceedings of the National Academy of Sciences 95, no. 21 (1998): 12637-40; Kirsten I. Bos et al., "A Draft Genome of Yersinia Pestis from Victims of the Black Death," Nature 478, no. 7370 (2011): 506-10.

27 For a recent overview of the world-wide epidemiology of plague, including an analysis of some unexplained aspects of its spread in Europe, see Samuel K. Cohn, "Epidemiology of the Black Death and Successive Waves of Plague," Medical History 52, no. S27 (2008): 74-100.

28 For example, the emergence of new art forms like Dances of Death suggest profound changes in attitudes in the 14th century. Effects on the economy were also huge: during and immediately after the Black Death economies collapsed, but in later years the reduction in population numbers and the resulting shortage of man-power led to wage increases and a rise of living standards; see Norman F. Cantor, In the Wake of the Plague (New York: Free Press, 2001). 
After this first wave, the plague retreated and returned in cyclical patterns, but until much later never disappeared entirely. Devastating epidemics in North-western Europe occurred as late as the 1620 and 166os, ravaging even capital cities like London and Amsterdam. Southern and Eastern Europe still experienced some plague epidemics in the 18th century, including an epidemic in the early 1720 s in Marseille (Southern France), one in the early 1740 s in Messina (Sicily), and one in the early 1770 in Moscow (Russia). In the 19th century, however, epidemics of plague were almost completely limited to South-eastern Europe. The decline of plague, including the last spikes in the 18th and 19th centuries, can clearly be seen in Figure $10 .{ }^{29}$

The gradual disappearance of plague from Europe has never been completely explained. Factors that have been considered - without much direct evidence - are a change in rat populations, a change from wooden to stonebuilt houses, increased immunity of rats or fleas, and decreased virulence of Yersinia pestis. While it is difficult to rule out such 'spontaneous' changes, there is also a lot to be said for an impact of intentional 'human agency', particularly public health measures. Plague was recognized as contagious early on, and in North-western and Southern Europe this resulted in the development and implementation of increasingly effective measures to prevent contagion. ${ }^{30}$

This included isolation of patients and disinfection of the houses of the deceased, forced quarantine of ships suspected of carrying infected persons, and military cordons to prevent infected persons and/or goods to leave or enter cities and countries. The first quarantine station was established in the Republic of Ragusa (modern-day Dubrovnik on the coast of Croatia) in 1377, and from the early 1400 s onwards the principalities of Italy established a sophisticated system of defence against plague and other infectious diseases that was kept in place for several centuries. This included an outer ring of armed sailing boats in the Mediterranean and the Adriatic, a middle ring of forts and observation towers on the Italian coast, and an inner ring of land-based cavalry to stop anyone and anything that had penetrated the first two rings. This system was

29 Figure 10 is based on counting the number of localities afflicted by plague, and not on counting numbers of people infected with or dying from plague. The gradual increase seen between the early 14th and mid-17th centuries is probably an artefact of the increasing availability of archival sources, or simply of the increasing numbers of inhabited localities. Most of the information in this section about the diffusion of plague through Europe comes from Jean Noël Biraben, Les Hommes et la Peste en France et dans les Pays Européens et Méditerranéens (Paris: Mouton, 1975) and Hirsch, Handbook vol. I, pp. 494-96.

3o See, e.g., Slack, "Black Death" and Cohn, "Epidemiology" for a balanced account of the factors involved in the decline of plague. 


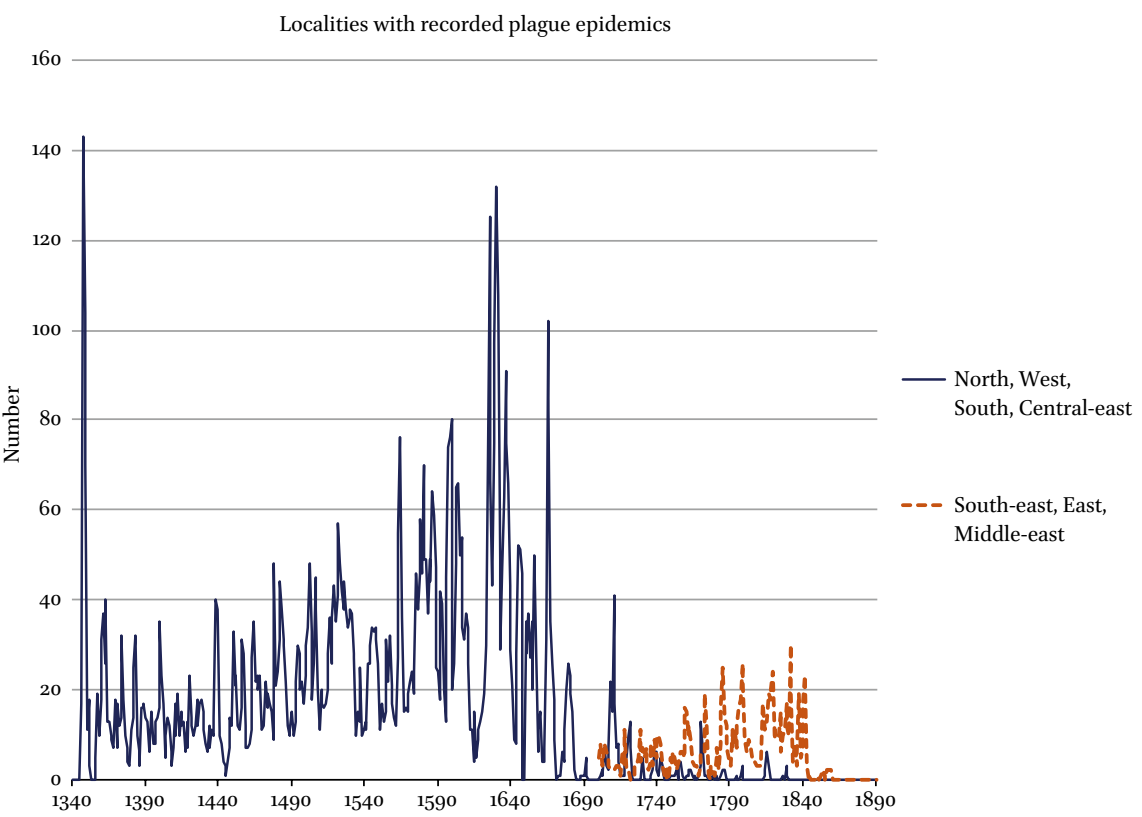

FIGURE 10 Plague epidemics in Europe and the Mediterranean, 1340-189o

Notes: Central-east includes North-western Russia; Middle-east includes Turkey and North Africa

SOURCE OF DATA: JEAN-NOËL BIRABEN. LES HOMMES ET LA PESTE EN

FRANCE ET DANS LES PAYS EUROPÉENS ET MÉDITERRANÉENS. PARIS:

MOUTON, 1975, ANNEXE III

not $100 \%$ water-tight, as illustrated by the 1743 epidemic in Messina, but has likely prevented many epidemics from entering the country. ${ }^{31}$

Another important countermeasure was the cordon sanitaire on the bordermore than 1000 kilometres long - between the Habsburg and Ottoman Empires. This was created by the Habsburg Empire during the 18th century, in order to prevent introduction of plague from the Ottoman Empire where the disease was still endemic. It was completed in 1770 and kept in place until the

31 On the Italian system of defence against plague, see Andrew D. Cliff, Matthew R. Smallman-Raynor, and Peta M. Stevens, "Controlling the Geographical Spread of Infectious Disease: Plague in Italy, 1347-1851," Acta Medico-Historica Adriatica 7, no. 2 (2009): 197236. Evidence for an effect of cordons sanitaires also includes the experience with the last great plague epidemics in France. In contrast to London, Paris could avoid the plague epidemic of the 166os, by a cordon sanitaire in the North of France, shielding it off from the Low Countries where Amsterdam was already struck by plague. France also stopped the plague epidemic of the 1720 s by a cordon sanitaire in Provence and Languedoc; see P. Bourdelais, Les Épidémies Terrassées. Une Histoire de Pays Riches (Paris: Éditions de la Martinière, 2003), Chapter 1. 
186os. It included a chain of military look-out posts, guarded frontier crossings, regulations for who and what could enter the Empire, and quarantine stations to isolate and disinfect suspicious people and goods. It also included a plague intelligence service in the Ottoman empire which could send timely warnings to step-up protection measures. Even though occasional lapses occurred, the implementation of this system coincided with the disappearance of plague from the Habsburg Empire. ${ }^{32}$

Plague did not disappear from all parts of Europe in the same pace, and the fact that it persisted longer in the South-east, as illustrated in Figure 10, supports the idea that preventive measures were at least partly responsible for the decline of plague. In the Ottoman Empire, both the largely illiterate public and the governing bodies were reluctant to implement the measures recommended by Western experts. During the first decades of the 19th century, yearly epidemics still occurred in the Balkans, then still part of the Ottoman Empire. It was not until the 1830 s that the Ottoman authorities, pressed by Western governments, adopted stricter measures to prevent the spread of plague, after which plague also disappeared from the South-east. ${ }^{33}$

\section{Smallpox}

In contrast to what its innocuous name suggests, smallpox was a big killer during Europe's Middle Ages and early modern period. This disease, which is caused by infection with the Variola virus, was probably already known to Galen (third century $\mathrm{CE}$ ), and received its first clear description from Persian physician Rhazes (854-925). It is likely that smallpox was already common in Southern Europe in the sixth century, and penetrated into Northern Europe during the Middle Ages, reaching Iceland in the 13 th century. ${ }^{34}$

Since then, regularly returning smallpox epidemics with a periodicity of between 5 and 15 years, depending on the size of populations, have been a constant feature of the European mortality pattern. It was mainly a disease of children, which not only caused skin vesicles and pustules, but in its malignant form also caused a high fever, septicaemia and extensive bleeding, leading to a

$32 \quad$ See Rothenberg, "Austrian sanitary cordon."

33 Due to international sanitary cooperation, the third pandemic of plague, which started in China in the 1850s, and reached Hong Kong, Bombay and Alexandria in the 189os, never reached Europe, with the exception of a small epidemic around Oporto (Portugal) in 1899; see Jo N. Hays, Epidemics and Pandemics: Their Impacts on Human History (Santa Barbara etc.: ABC-Clio, 2005), Chapter 36.

34 The name of smallpox derives from the distinction, made in the $15^{\text {th }}$ century, with another disease that caused somewhat similar skin eruptions and that was labelled "the Great pox": syphilis. For a history of smallpox epidemics, see, e.g. Hirsch, Handbook vol. I, pp. $123-53$. 
high case fatality. In the 18th century, in the European countries or large cities that already kept cause-of-death statistics, smallpox accounted for around $10 \%$ of all deaths, and a much higher proportion of deaths among children. ${ }^{35}$

Yet, smallpox has gone: the last cases world-wide occurred in the 1970s, and smallpox largely disappeared from Europe in the 19th and first half of the 2oth century, mainly as a result of vaccination. ${ }^{36}$

The core of this success story is well-known and can therefore be summarized in a few sentences. In Asia it had already been known for a long time that 'inoculation' of healthy persons with infected material from smallpox patients protected them from smallpox. In the early 18th century this procedure was imported into Europe from the Ottoman Empire, and although inoculation carried a substantial risk, it was used on a wide scale in England and several other European countries. In the early decades of the 19th century it was rapidly replaced by the safer procedure of 'vaccination', which was discovered at the end of the 18th century and used infected material from cows suffering from cowpox. ${ }^{37}$

Vaccination immediately became very popular, and was promoted by the medical profession, Royal Commissions, national parliaments and voluntary organizations all over Europe. While it is likely that inoculation already reduced mortality from smallpox in the 18th century, vaccination certainly and substantially reduced mortality from smallpox in the 19th century. Studies comparing the mortality rates from smallpox before and after the introduction of vaccination show a reduction of between 50 and $90 \%{ }^{38}$

Continuous series of cause-specific mortality spanning this period are rare, and limited to the Nordic countries and a few of Europe's largest cities. In Finland and Sweden, mortality from smallpox started to decline precipitously

35 See, e.g., Kari J. Pitkänen, James H. Mielke, and Lynn B. Jorde, "Smallpox and Its Eradication in Finland: Implications for Disease Control," Population Studies 43, no. 1 (1989): 95111, on mortality from smallpox in 18th century Finland, and Mercer, Disease on mortality from smallpox in 18th century London.

36 It has been argued that vaccination coverage in European countries in the 19th centuries was not high enough to completely explain the decline of smallpox, and that spontaneous declines in virulence must also have played a role; see A.B. Christie, "Smallpox," in World Geography of Human Diseases, ed. G. Melvyn Howe (London etc.: Academic Press, 1977).

37 On the use of inoculation during the 18th century, see Peter Razzell, The Conquest of Smallpox (Firle: Caliban Books, 1977). The discovery of vaccination is associated with the name of the English physician Edward Jenner (1749-1823), who systematically tested the effectiveness of 'vaccination' and disseminated the results in a scientific publication (Edward Jenner, An Inquiry into Causes and Effects of the Variolae Vaccinae (London: Sampson Low, 1798)).

38 The studies cited relate to parts of Germany and the Austro-Hungarian Empire. See Mercer, Disease, table 3.2. 


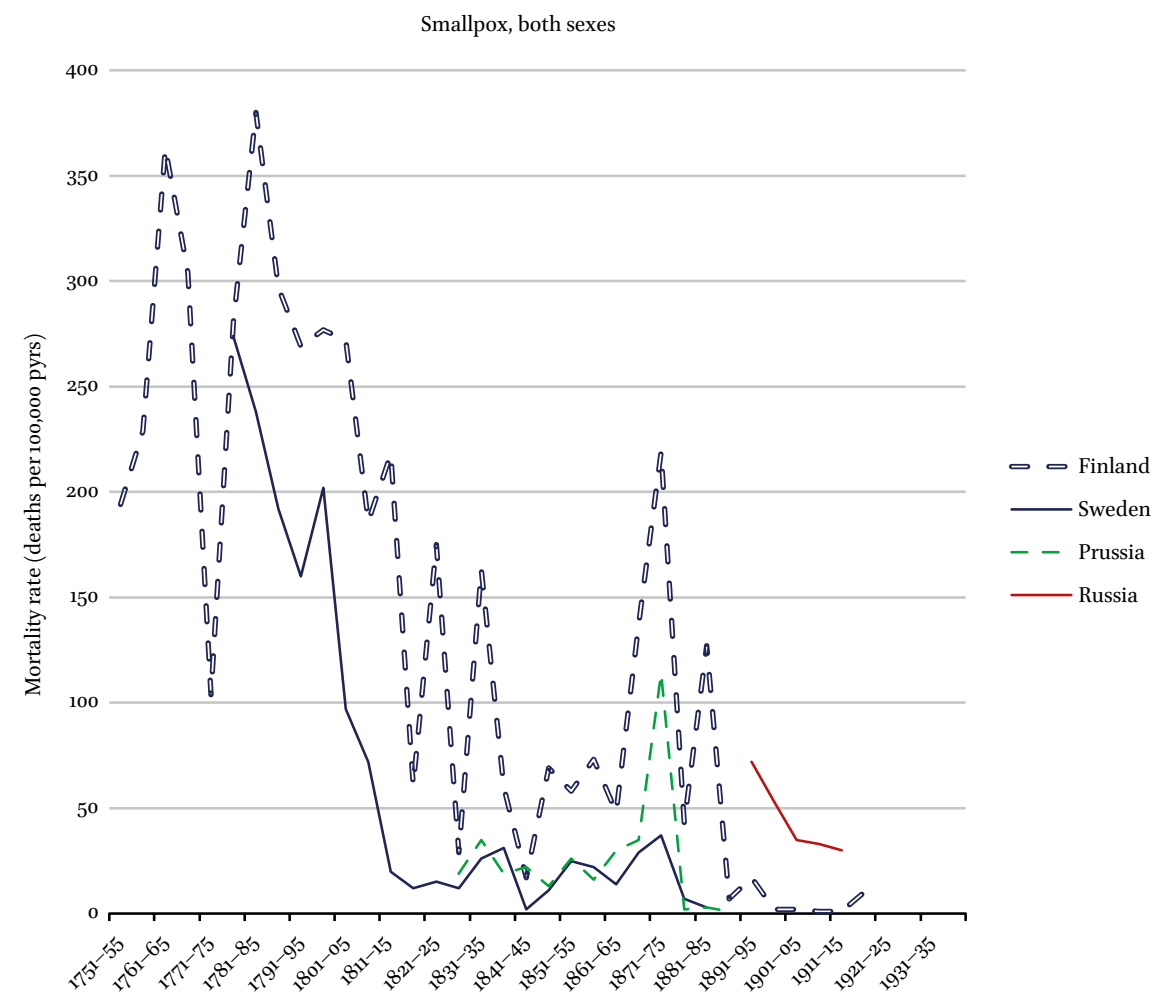

FIGURE 11 Trends in smallpox mortality in selected European countries, 1751-1935 Notes: Quinquennial data

SOURCE OF DATA: KARI J. PITKÄNEN, JAMES H. MIELKE, AND LYNN B. JORDE. "SMALLPOX AND ITS ERADICATION IN FINLAND: IMPLICATIONS FOR DISEASE CONTROL." POPULATION STUDIES. 43, NO. 1 (1989): TABLE 4

around the turn of the 19th century, but rose again during the severe 1870 pandemic. This struck many European countries, including the Netherlands and Prussia for which data are available from the 1860 o onwards (Figure 11). The fact that smallpox mortality during this pandemic rose less in Sweden and Denmark than in Finland, the Netherlands and Prussia has been ascribed to the fact that in the former two countries vaccination was compulsory. In the latter three it was voluntary only, so that vaccination rates had gradually declined in the preceding decades when smallpox epidemics became less frequent. ${ }^{39}$

39 See Pitkänen et al., "Smallpox and Its Eradication in Finland" for an analysis of trends in Finland and other European countries. The comparison between countries with compulsory and voluntary vaccination has been made in Willibrord Rutten, 'De Vreselijkste Aller Harpijen' (Wageningen: Afdeling Agrarische Geschiedenis, Landbouwuniversiteit Wageningen, 1997), table 11.6. The spread of smallpox during this epidemic was promoted by the demobilization of German and French troops after the 1871 Franco-Prussian War. 
A similar decline of smallpox mortality can be seen in some of Europe's larger cities. While the London 'Bills of Mortality' show a modest reduction of mortality from smallpox during the 18th century, a precipitous decline started around the turn of the 19th century. The success of smallpox vaccination has contributed importantly to the suppression of mortality crises, and may have played an important role more generally in the decline of mortality in Europe during the 19 th century. ${ }^{40}$

It took until the middle of the 2oth century, however, before smallpox completely disappeared from Europe. In the first decades of the 2oth century, there was still appreciable mortality from smallpox in Spain, Portugal, and Greece, as well as in Finland, and occasional deaths still occurred in many other countries. After World War II, Portugal was the last of the European countries in which smallpox mortality became a disease of the past. ${ }^{41}$

\section{Typhus}

More than the history of any other infectious disease, "[t]he history of typhus is written in those dark pages of the world's story which tell the grievous visitations of mankind by war, famine, and misery of every kind." The disease is characterized by high fever, headache and red spots on the skin (from which its other name, 'spotted fever', derives), and is caused by infection with Rickettsia prowazeki, a micro-organism transmitted between humans by the body louse. ${ }^{42}$

Because the symptoms of typhus are not very distinctive, it is difficult to trace its history, and before the middle of the 19th century it was often confused with what we now call 'typhoid', an intestinal infection. Bacteriologist Hans Zinsser, who wrote a classic history of typhus just before World War II (Rats, Lice and History), thinks that the disease arrived in Europe from Asia in

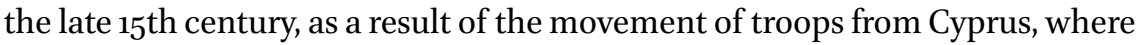
they had fought against the Turks, to Spain. From Spain, the disease eventually spread towards the North, but it may well have been introduced into Europe on several occasions, e.g., during confrontations with the Turks on the AustroHungarian front-line.

Over time, typhus spread to all parts of Europe, particularly during the many wars that were fought in the 17th century. It became endemic in Ireland, Italy and Russia where epidemics were frequent even in peace-time. Elsewhere, typhus epidemics mainly flared up whenever war erupted or famines occurred.

\footnotetext{
40 Some authors, such as Mercer, Disease, have claimed that smallpox vaccination was even the most important cause of mortality decline in this period. As seen in Michael Alderson, International Mortality Statistics (New York: Facts on File, 1981), table 32 . 
Numbers of deaths were often enormous, and in several European wars more men were lost through typhus than through action on the battlefield. The wellknown decimation by typhus of Napoleon's troops during the invasion of Russia is just one of many examples, as is the role of typhus in causing massive mortality during the 'Great Irish Famine'.43

Although improvements in personal hygiene, and the industrial production of soap for washing bodies and clothes, gradually reduced exposure to typhus in the more advanced European countries during the 19th century, targeted prevention became feasible only with the discovery in 1909 of its mode of transmission through the bites of the body louse. 'De-lousing' then proved an effective counter-strategy, and was at first carried out by a cumbersome process of bathing of bodies and heating of clothes. This was later replaced by the more practical 'fumigation' with DDT powder, which could be sprayed through sleeves and neck openings and did not require people to take off their clothes. ${ }^{44}$

A major typhus epidemic raged during the Balkan Wars (1912-13) and then again during World War I in Serbia, where 150,00o deaths occurred in a population of just 3 million, as well as 35,000 deaths among 70,000 Austrian prisoners-of-war. During and immediately after World War I, in the chaotic years following the October Revolution, an even more massive typhus epidemic accompanied Civil War and famine in Russia, and caused no less than 3 million deaths (Plate 9 and Suppl. Figure 8). This inspired Lenin to his famous appeal: "Comrades, we must concentrate everything on this problem. Either the lice will defeat socialism, or socialism will defeat the lice!". Large typhus epidemics also occurred in Poland, during the Russo-Polish war (1919-1922), and in Greece, due to the forced population movements during the expulsion of Greeks from Turkey (1922). ${ }^{45}$

Because these epidemics threatened to spread through Europe from East to West, an internationally coordinated action was mounted. Alarming reports by the Red Cross and the Rockefeller Foundation accelerated the formation of the

43 The fascinating history of typhus, including its role in deciding the outcome of wars, has been written several times, but most engagingly in Hans Zinsser, Rats, Lice and History (London etc.: Routledge [re-edition by Penguin Books in 2000], 1935). DNA testing of the remains of French soldiers of Napoleon's retreating army, buried in a mass grave in Vilnius, have confirmed the presence of Rickettsia prowazekii in their dental pulp; see Didier Raoult et al., "Evidence for Louse-Transmitted Diseases in Soldiers of Napoleon's Grand Army in Vilnius," Journal of Infectious Diseases 193, no. 1 (2006): 112-20.

44 For the history of soap, see John A. Hunt, "A Short History of Soap," Pharmaceutical Journal 263, no. 7076 (1999): 985-89. The development of de-lousing strategies and their benefits during World War I and II are described in John C. Snyder, "Typhus Fever in the Second World War," California Medicine 66, no. 1 (1947): 3-10. During World War II, a vaccine was developed, but this proved to be unsafe.

The quote from Vladimir Lenin can be found in his Collected Works, Vol. 30, p. 228. 


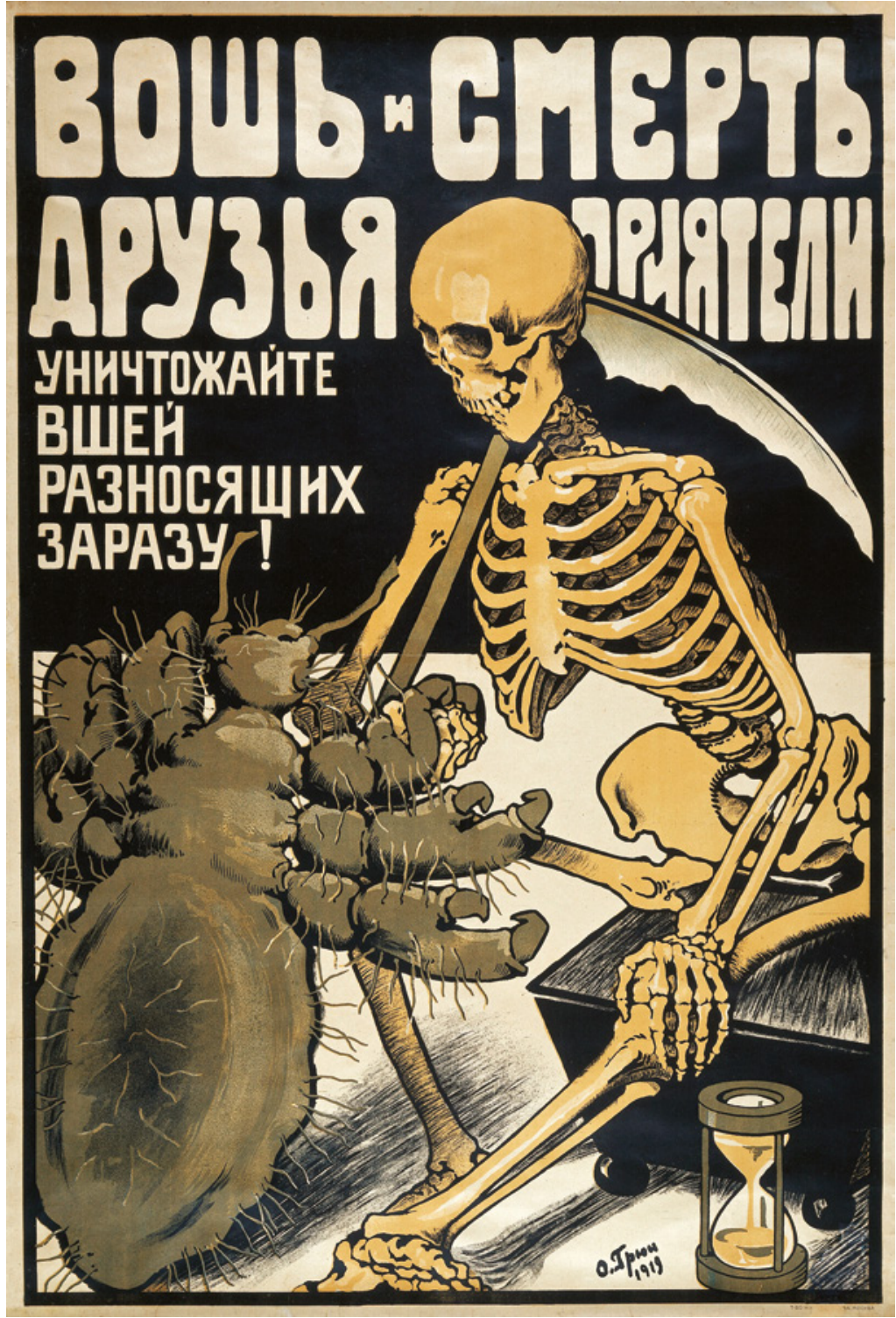

PLATE 9 "The louse and death are friends." Russian poster warning against typhus, 1919 This poster dates from the Russian Civil War, in which the Bolsheviks fought the White Army defending the pre-Revolution status quo. This terrible war was accompanied by famine and epidemics, including a huge typhus epidemic. Translation of the Russian text: "The louse and death are friends and comrades. Kill all lice carrying infection!" COLOUR LITHOGRAPH BY O. GRIN. WELLCOME COLLECTION (CC BY 4.0) 
League of Nations Health Organization (LNHO) and its Epidemic Commission, which saw the control of typhus in Europe as one of its first priorities. With some international support, the government of newly independent Poland established a network of quarantine and de-lousing stations, in order to prevent further spread of typhus with the massive movements of people through its territory. ${ }^{46}$

After these episodes typhus kept returning to Europe, e.g., during the $1930 \mathrm{~s}$ famine in Ukraine and Russia, during the Spanish Civil War (1936-39), and during World War II on the Eastern front, in German concentration camps, and in the Warsaw ghetto. Over-all, however, due to more effective countermeasures typhus made less casualties in and after World War II than in and after World War I.

Typhus is one of those diseases that easily lend themselves for metaphorical use, sometimes in a highly malicious way. The association with misery and lack of hygiene implied that typhus also occurred more frequently among the impoverished Jewish populations in Central and Eastern Europe. This was wellknown in Germany, and in the 1930s and 1940s the Nazis used this association to reinforce antisemitism, and portrayed the Jews not only as bringers of typhus, but as a metaphorical typhus that needed to be eliminated. Gassing the Jews in concentration camps like Auschwitz thus - horrendously - became a form of 'de-lousing' the Aryan race. ${ }^{47}$

\section{Malaria}

Malaria is a very wide-spread disease. It can be caused by infection with four different species of Plasmodium parasites, which in their turn are transmitted by many different species of Anopheles mosquitoes. The disease probably originated in Africa, but after the Neolithic agricultural revolution established itself in the river basins of the civilizations of India, China, Mesopotamia and Egypt, from where it also reached the Mediterranean. From these original foci it spread to most of the tropical and to large parts of the temperate world.

In Europe, malaria has been prevalent nearly everywhere, even above the Arctic circle, but with a predilection for marshy regions. It occurred both in an endemic and an epidemic form. Malaria was endemic in many European regions, causing a general weakness and increased mortality from various

46 For the history of typhus control in Poland, see Francesca Piana, "Humanitaire et Politique, in Medias Res," Relations Internationales 2, no. 138 (2009): 23-38. Polish bacteriologist and public health pioneer Ludwik Rajchman (1881-1965) was the first chairman of the League of Nations Health Organization, and led some of the epidemic reconnaissance trips into Russia and Poland. For his biography, see Marta A. Balińska, For the Good of Humanity (Budapest: Central European University Press, 1998). 
other causes in all years, particularly among children. It also occurred in epidemics which caused peaks of mortality even outside endemic regions. A first documented epidemic overran most of Europe in the 1550s, and again repeatedly thereafter, with at least four large epidemics in the 18th and five in the 19th century. 48

Like epidemics of typhus, epidemics of malaria were often associated with warfare. Some of the last epidemics in Europe occurred after World War I in Southern, South-eastern and Eastern Europe. They were due to catastrophic social and medical conditions, large numbers of refugees carrying parasites, and infection of previously non-exposed populations. Some smaller epidemics occurred as recently as in World War II, even in the Netherlands.

In North-western Europe, malaria started to regress in the 18th century, with countries in the South and East following later, and some European countries were only declared malaria-free in the 1950s. Although the start of the decline long antedated the discovery of the malaria parasite in 1880 , this regression was not spontaneous.

Much of the early decline was related to what we have called "changes in living conditions, pursued for reasons indirectly related to health" (Chapter 1). Expansion of agriculture required drainage of lands formerly infested with mosquitoes. Improvements in agricultural methods led to higher yields and better nutrition which increased human resistance, and where cattle breeding increased this reduced mosquito bites to humans. Over time, however, the role of disease control measures in the decline of malaria increased. This is clear from the fact that several of the malaria control measures that we now know to be effective, were already applied in the 19th century, on the basis of incomplete or even incorrect knowledge of the causes of this disease.

Five groups of effective measures are currently distinguished: (1) Prevention of mosquito bites, e.g., by screening of windows. (2) Reduction of mosquitobreeding by eliminating collections of water, e.g., by draining marshes. (3) Reduction of mosquito larvae, e.g., by applying chemicals to breeding waters. (4) Reduction of adult mosquitoes, e.g., by applying insecticides to housing areas. (5) Elimination of malaria parasites in the human host, e.g., by anti-malarial drugs. Scientific discussions on the best way to control malaria have continued

48 The information on trends and distribution of malaria in this section is based on Hirsch, Handbook, vol. I, pp. 197-315, and on Andrew T.A. Learmonth, "Malaria," in World Geography of Human Diseases, ed. G. Melvyn Howe (London etc.: Academic Press, 1977); Leonard J. Bruce-Chwatt and Julian De Zulueta, The Rise and Fall of Malaria in Europe (Oxford etc.: Oxford University Press, 1980); Randall M. Packard, The Making of a Tropical Disease (Baltimore: Johns Hopkins University Press, 2007). 
throughout the 2oth century, but it has been shown that in different settings different combinations of measures have worked well. ${ }^{49}$

As indicated above, in the 18th and 19th centuries draining marshes (strategy 2) was undertaken on a large scale, and while this was at first done mainly for economic reasons, later it was also done because of the known association between malaria and stagnant water. The effectiveness of quinine in reducing case fatality in malaria (strategy 5) was already discovered in the $17^{\text {th }}$ century, and in the 19th century quinine was used extensively in the treatment of malaria. ${ }^{50}$

In the 2oth century, malaria eradication has been in the focus of public health authorities in many European countries, and also of international organizations like the League of Nations and the Rockefeller Foundation, particularly in the period between the two World Wars. In the 1940s, the development of DDT, an insecticide which after a single spraying provided longer-term protection against mosquitoes, briefly suggested that malaria could be eradicated. Unfortunately, this turned out to be a false hope when mosquitoes became resistant.

Italy, under a fascist government, had an ambitious program to tackle malaria, which focused on drainage and land reclamation. Spain, another country where malaria was still endemic in large areas in the beginning of the 2oth century, also had a national anti-malaria program which, despite resistance of large land-owners, gradually succeeded in pushing back the disease. For newly formed Yugoslavia, anti-malaria programs had a dual purpose: tackling malaria and showing the benefits of nationhood to the newly united Southern Slavs. Starting in the 1920s, the Soviet Union also had a massive program - admired by foreign observers - to push back malaria, carried out by a network of thousands of anti-malaria stations and temporary paramedical detachments.

These efforts gradually eradicated endemic malaria from Europe, as shown in Figure 12. Spain (marked in the graph), Portugal, Italy and Greece still had many cases each year during the 1930s, although a decline can already be seen in the late 1930s in Italy. Spain saw a resurgence starting during its Civil War, but this reversed into a rapid decline in the late 1940s. Russia and later the Soviet Union had millions of cases each year before and after World War I, culminating in almost 10 million cases in 1934, but rapidly got rid of malaria in the late 1940 s and $1950 \mathrm{~s}$.

49 Patrick Zylberman, "A Transatlantic Dispute," in Shifting Boundaries of Public Health, ed. Susan Gross Solomon, Lion Murard, and Patrick Zylberman (Rochester: University of Rochester Press, 2008).

5o Medical scientists in the 19th century believed that many diseases that are now considered to be infectious, found their origins in a 'miasma': noxious air emanating from rotting organic material in the soil. The term 'malaria' (literally: "bad air") still refers to this theory which is now obsolete, but did inspire effective public health interventions. 


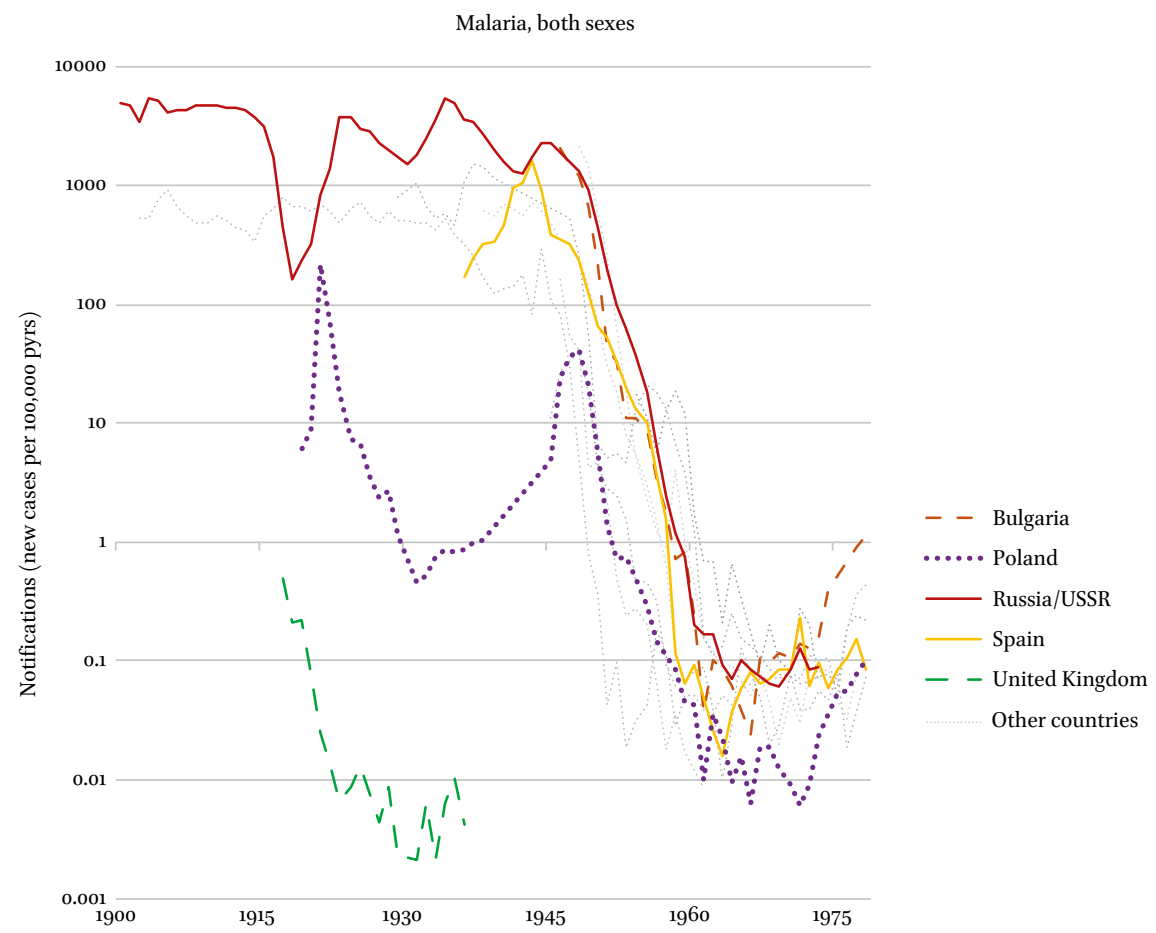

FIGURE 12 Trends in malaria incidence in Europe, 1900-1978

Notes: Logarithmic scale SOURCE OF DATA: LEONARD J. BRUCE-CHWATT AND JULIAN DE ZULUETA. THE RISE AND FALL OF MALARIA IN EUROPE OXFORD ETC.: OXFORD UNIVERSITY PRESS, 1980. VARIOUS TABLES

The decline of malaria in Europe, which probably started in the 18th century, was accompanied - and not entirely coincidentally - by a rise of malaria at the other side of the world, i.e., in the larger Caribbean. The creation of sugar plantations in which black slaves from Africa were put to work, helped develop Europe's economy, but also introduced endemic malaria in the South-eastern United States, on Caribbean islands, and in North-eastern Brazil. ${ }^{51}$

More recently, the rise of global traveling increased the numbers of imported cases, and climate change threatens to bring endemic malaria back, particularly in Southern Europe.

$5^{1} \quad$ John R. McNeill, Mosquito Empires (Cambridge etc.: Cambridge University Press, 2010). 